\title{
Pengaruh Pupuk Organik Berbahan Dasar Cairan Flushing Kandang Terhadap Pertumbuhan Rumput Raja (Pennisetum purpoides L.)
}

\author{
Nadia Nuraniya Kamaluddin11, Rija Sudirja1), Eso Solihin1), Suryo Firmato² \\ 1)Departemen Ilmu Tanah dan Sumberdaya Lahan, Fakultas Pertanian Universitas Padjadjaran \\ Jl. Raya Bandung Sumedang Km 21 Jatinangor, Sumedang \\ 2) PT. Ultra Pertanian Bandung Selatan, Jalan Raya Pangalengan No. 340, Margamekar, Pangalengan \\ 40378 Bandung, Jawa Barat \\ Korespondensi: nadia@unpad.ac.id
}

\begin{abstract}
Dairy farming waste in high volume especially in the form of flushing slurry can be unmanageable. Flushing slurry is lower in organic matter content compared to solid waste due to water saturation. In order to enhance the utilization, flushing slurry can be converted in liquid organic fertilizer with higher nutrient content. King grass (Pennisetum purphoides L.) plant is commonly used as livestock feed especially dairy cow in South Bandung area. The experiment was conducted between March to June 2018 in Pangalengan, South Bandung. The result shows no significant different between control specimen and liquid organic fertilizer teratments in plant hight, number of leaves, root weight, and root length. Although notable amount of plant leaves was demonstrated in D treatment compared to than that of control.
\end{abstract}

Keywords: flushing, slurry, king grass, organic fertilizer

\section{PENDAHULUAN}

Proses pengembangan usaha peternakan seyogyanya tidak hanya mementingkan hasil produk usaha seperti susu atau pun daging tetapi juga harus memperhatikan keadaan lingkungan sekitarnya. Produk sampingan dari kegiatan peternakan sapi perah dapat berupa limbah berbentuk padat dan cair yang diharus dikelola dengan baik, untuk mencegahnya pencemaran kepada tanah atau badan air lingkungan sekitar. Kegiatan peternakan sapi perah menghasilkan beberapa produk samping yang tidak diinginkan salah satunya adalah cairan sisa pembersihan kandang atau flushing.

Cairan flushing berada dalam bentuk campuran kotoran sapi padat dan cair disertai dengan sejumlah air yang lebih dikenal dengan slurry. Slurry pada pertanian mencapai $20 \%$ dari total limbah namun membutuhkan 7,9 kali lipat area pengolahan dibandingkan dengan kotoran padat (Shima et al., 2002). Perlakuan terhadap slurry hasil flushing kandang seringkali menyulitkan karena memiliki viskositas, volume, dan masa jenis yang tinggi dibandingkan dengan pupuk kandang.

Cairan flushing kandang dapat menjadi produk bernilai tinggi dalam bidang tinggi karena mengandung nutrisi dan bahan organik yang bermanfaat bagi tanaman dan tanah (Cavalli et al., 2014). Slurry flushing kandang memiliki kadar N-tersedia lebih tinggi yaitu 4481\% (Möller dan Müller, 2012) dibandingkan dengan campuran kotoran segar 40-60\% (Gutser et al., 2012). Kotoran sapi perah yang mengonsumsi $17,8 \mathrm{~kg}$ pakan kering per hari diperkirakan mengandung $296 \mathrm{~g}$ N-total, $112 \mathrm{~g}$ $\mathrm{NH}_{3}, 183 \mathrm{~g}$ fosfat, $54 \mathrm{~g}$ kalium, dan $55 \mathrm{~g}$ besi dari total 56,7 kg slurry kotoran dengan kadar air 87,8\% (Van Horn et al., 2008).

Salah satu bentuk pengelolaan limbah yang dapat dilakukan adalah melalui pengolahan cairan flushing kandang menjadi pupuk organik padat. Melalui pengolahan ini, limbah dapat diubah menjadi produk pupuk atau pembenah tanah yang dapat memperbaiki sifat fisik dan kimia tanah serta sebagai nutrisi tanaman. 
Rumput raja (Penisettum purpoides L.) merupakan pakan ternak yang dapat dikonsumsi segar ataupun dalam bentuk silase. Rumput raja mengandung $93.7 \%$ bahan kering, $86.31 \%$ zat organik, dan $23.57 \%$ protein kotor (Asikin et al., 2018) yang cocok untuk pakan sapi perah. King grass tumbuh berumpun dan umumnya terdiri atas 20-50 batang dengan diameter sekitar 2,5 cm. Tinggi king grass dapat mencapai 2-3m dengan lebar daun 2$3 \mathrm{~cm}$ (Kushartono, 1998).

Penelitian ini bertujuan untuk mengetahui pengaruh pupuk organik cair berbahan dasar cairan (slurry) flushing kandang terhadap parameter pertumbuhan rumput raja seperti tinggi tanaman, jumlah daun, panjang dan bobot akar.

\section{METODOLOGI}

Penelitian ini dilakukan di lahan percobaan PT. Ultra Peternakan Bandung Selatan, Margamekar, Pangalengan dari bulan Maret hingga Juni 2018. Analisis tanah dilakukan di Laboratorium Kesuburan Tanah dan Nutrisi Tanaman, Fakultas Pertanian, Universitas Padjadjaran.

Bahan yang digunakan dalam penelitian ini adalah media tanam berupa tanah Andisols Pangalengan seberat $20 \mathrm{~kg}$ per polybag, bibit Pennisetum purphoides L. berusia 2 minggu, Pupuk Organik Cair, dan insektisida merk Furadan. Alat yang digunakan adalah: timbangan analitik, cutter, meteran kelos, alat tulis, emrat, dan peralatan laboratorium.

Cairan flushing kandang terlebih dahulu diukur kandungan unsur haranya dan diformulasi agar sesuai dengan baku mutu yang tercantum dalam Peraturan Menteri Pertanian No. 70 Tahun 2011 (Permentan No. 70). Kandungan unsur hara setelah formulasi adalah: C-organik 8.52\%, N-total 4.10\%, P-total $3.15 \%$ dan $\mathrm{K}_{2} \mathrm{O} 3.32 \%$.
Metode pengujian pupuk organik mengacu kepada Permentan 70. Pelaksanan pengujian ini menggunakan pengujian dengan menggunakan metode Rancangan Acak Kelompok dengan tiga kali ulangan. Perlakuan yang diaplikasikan pada penelitian ini adalah:

- $\operatorname{Kontrol}(\mathrm{A})$,

- 1 Dosis NPK Standar (B),

- 1 Dosis POC(C),

- 0,25 Dosis NPK Standard dan 1 Dosis POC (D),

- 0,5 Dosis NPK Standard dan 1 Dosis POC (E),

- 0,75 Dosis NPK Standard dan 1 Dosis POC (F),

- 1 Dosis NPK Standard dan 1 Dosis POC (G),

- $\quad$ 0,75 Dosis NPK Standard dan 0.25 Dosis POC $(\mathrm{H})$,

- Dosis 0,75 NPK Standard dan 0.5 Dosis POC (I), dan

- $\quad$ 0,75 Dosis NPK Standard dan 0.75 Dosis POC (J).

Satu dosis NPK adalah sebesar $200 \mathrm{~kg} / \mathrm{ha}$ dan satu dosis POC adalah 5l/ha.

Respon yang diamati yang diamati dalam penelitian ini adalah tinggi tanaman dan jumlah helaian daun yang diukur setiap 7 hari setelah tanam (HST), serta panjang dan berat akar tanaman rumput raja (Pennisetum purphoides) yang diukur pada 60 HST. Respon kuantitatif yang diperoleh dianalisis menggunakan uji Independent Student-T dengan tingkat kepercayaan 5\%.

\section{HASIL DAN PEMBAHASAN}

\subsection{Tinggi Tanaman}

Berdasarkan hasil analisis sidik ragam dapat dilihat bahwa pada usia 7 HST pertambahan tinggi tanaman berpengaruh tidak nyata untuk setiap perlakuan. Pertambahan tinggi tanaman juga masih dalam nilai yang kecil. Hal ini dapat disebabkan oleh tanaman yang baru 
dipindah tanamkan dan masih beradaptasi dengan lingkungan yang baru.

Pengaruh dari perlakuan NPK, POC, dan kombinasinya baru menunjukkan adanya perbedaan pada usia 14 HST. Meskipun demikian, sampai panen di usia 60 HST, seluruh perlakuan tidak memberi hasil yang berbeda nyata antar perlakuan. Tinggi saat panen pada perlakuan I mencapai 198,6 cm dibandingkan perlakuan D yang mencapai 115,1 cm (Gambar 1). Hal ini menunjukkan apabila aplikasi pupuk anorganik dikurangi dalam jumlah relatif besar, maka kebutuhan hara tanaman kurang dapat dipenuhi. Hal ini dapat disebabkan belum nitrogen pada flushing kandang masih dalam bentuk terikat sehingga tidak tersedia bagi tanaman.

Menurut Schröder (2005) pada awal aplikasi pupuk kandang, $\mathrm{N}$ relatif kurang tersedia bagi tanaman, namun mineralisasi $\mathrm{N}$ dalam tanah akan meningkat setelah tahun kedua. Pemberian pupuk anorganik dapat memenuhi kebutuhan unsur hara nitrogen bagi tanaman pada awal aplikasi perlakuan cairan flushing pada tanah. Pupuk anorganik merupakan pupuk hasil industri yang mengandung unsur hara dalam kadar tinggi dan cepat tersedia bagi tanaman.

\subsection{Jumlah Daun}

Hasil analisis uji independen menunjukkan bahwa dari usia tanaman 7 HST sampai 60 HST tidak ada perbedaan yang signifikan antar perlakuan (Gambar 2). Namun pada perlakuan D (0,25 Dosis NPK + 1 Dosis POC) rerata pertambahan helai daun mencapai 11,3, hal ini menunjukkan bahwa pemberian pupuk organik cair dapat membantu pembentukan daun hingga batas tertentu.
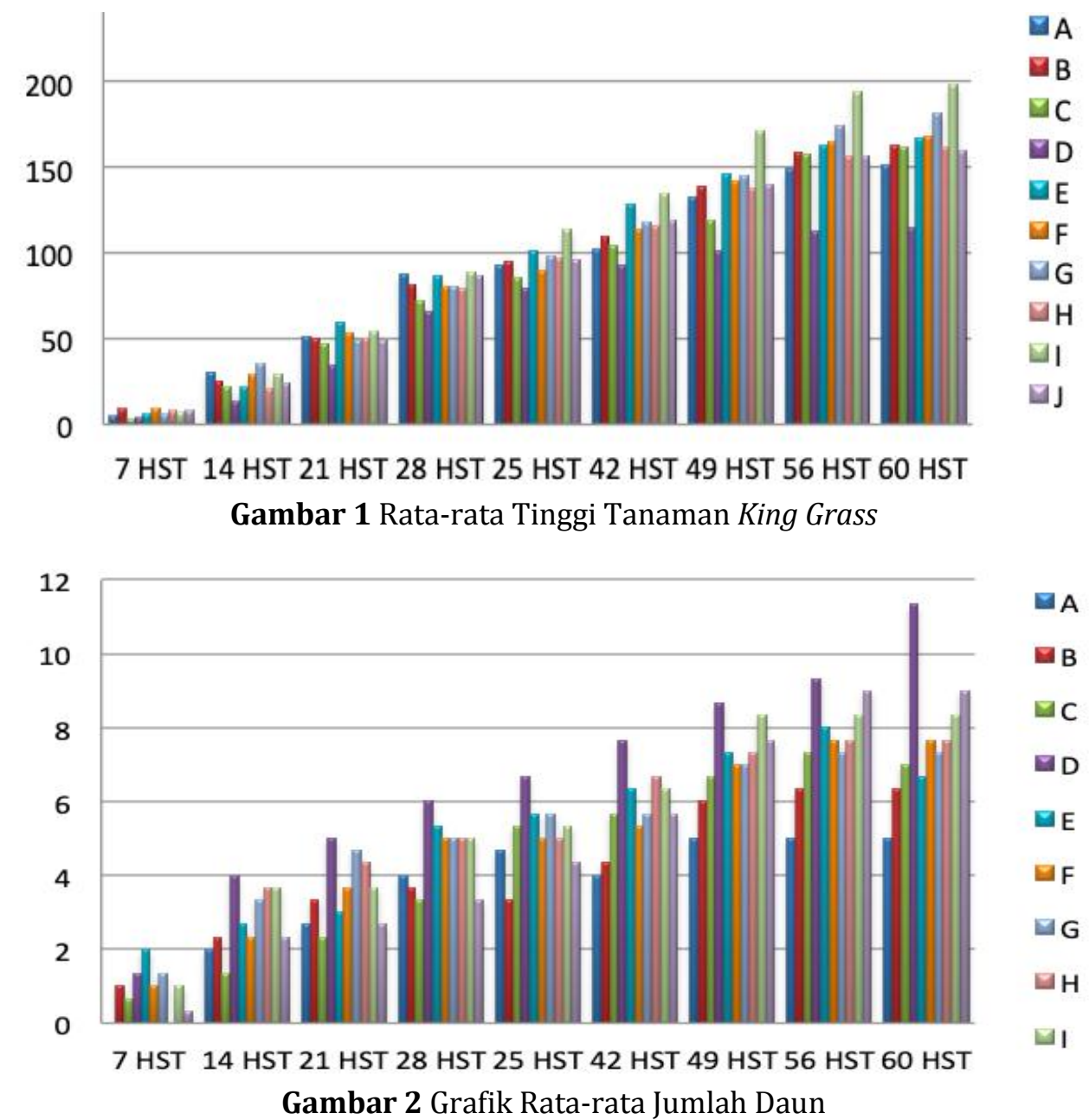
Unsur hara pada pupuk organik berbahan dasar cairan flushing dapat membantu memenuhi pertumbuhan karena mengandung unsur hara esensial dalam jumlah yang memadai bagi pertumbuhan tanaman king grass. Pemberian pupuk organik mempercepat sintesis asam amino dan protein sehingga mempercepat pertumbuhan tanaman (Parman, 2007).

\subsection{Panjang dan Berat Akar}

Hasil analisis menunjukkan bahwa seluruh perlakuan tidak berpengaruh nyata terhadap panjang akar tanaman (Gambar 3) dan tidak berbeda nyata antar perlakuan pada berat akar (Gambar 4). Akar terpanjang adalah akar dari perlakuan kontrol begitu pula dengan berat akar.

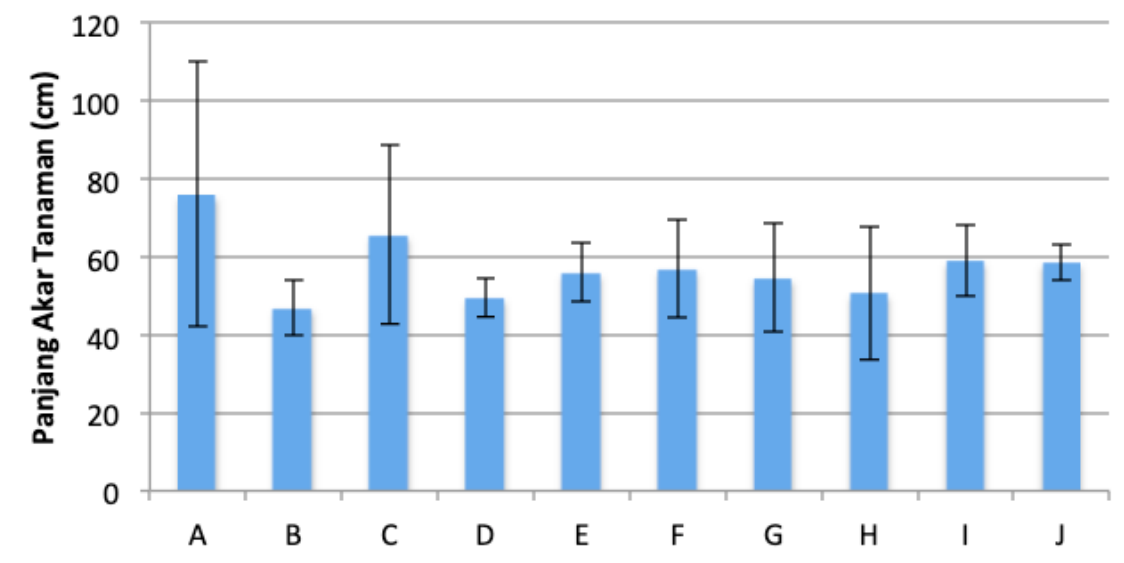

Gambar 3 Rata-rata Panjang Akar Tanaman

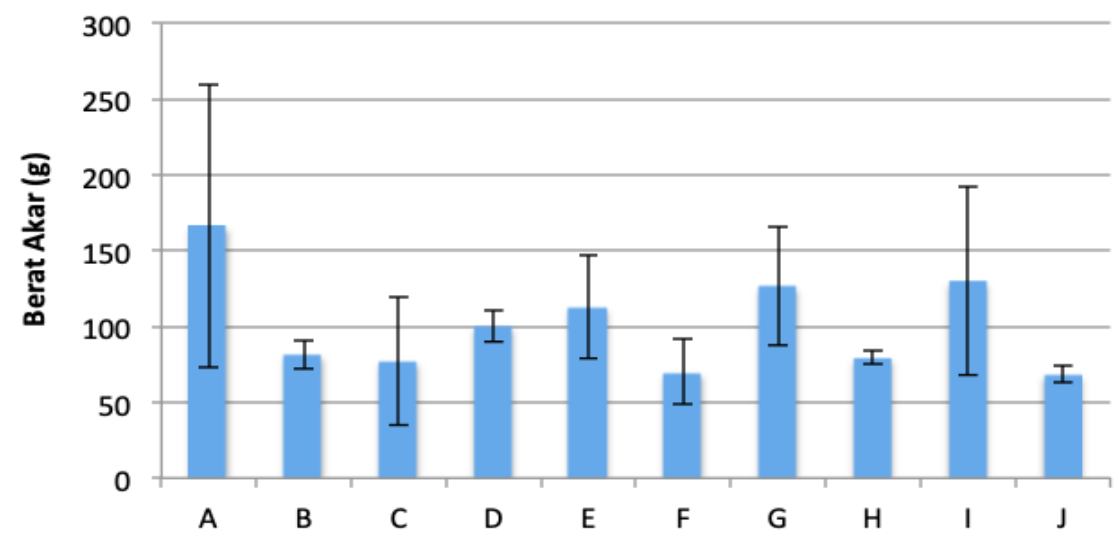

Gambar 4 Rata-rata Berat Akar Tanaman

\section{KESIMPULAN}

Pupuk organik cair berbahan dasar cairan slurry flushing kandang tidak berpengaruh nyata terhadap tinggi tanaman, jumlah helai daun, panjang akar, dan berat akar. Hal ini dapat disebabkan dengan cukupnya unsur hara pada tanah Andisols Pangalengan yang digunakan sehingga pengaruh pemupukan tidak terdeteksi.

\section{DAFTARPUSTAKA}

Asikin, N., Jayanegara, A., Ridla, M., Samsudin, A. A. 2018. The potential of tropical grass as a feed in ruminant by using an in vitro reduction. MATEC Web of Conference 197, 06005 (2018): 1 - 3.

Cavalli, D., Cabassi, G., Borrelli, L., Fuccella, R., Degano, L., Bechini, L., \& Marino, P. 2014. Nitrogen fertiliser value of 
digested dairy cow slurry, its liquid and solid fractions, and of dairy cow slurry. Italian Journal of Agronomy, 9(567), 71-78.

Gutser, R, Th. Ebertseder, A. Weber, M. Schraml, U. Schmidhalter. 2005. Short-term and residual availability of nitrogen after long-term application of organic fertilizers on arable land. J Plant. Nutr. Soil Sci. 168:439-446.

Jadid M. N. 2007. Uji Toleransi Aksesi Kapas (Gossypium hirsutum L.) terhadap Cekaman Kekeringan dengan Menggunakan Polietilena Glikol (PEG) 6000. Fakultas Sains dan Teknologi Universitas Islam Negeri Malang, Malang. Skripsi.

Kushartono, B. 1998. Teknik penanaman rumput raja (king grass) berdasarkan prinsip penanaman tebu. Dalam Kalsid, E (Ed.). Prosiding Lokakarya Fungsional Non Peneliti. Pusat Penelitian dan Pengembangan Peternakan. Bogor 15 - 16 Desember 1997. Hal: $85-91$.

Möller K, Müller T, 2012. Effects of anaerobic digestion on digestate nutrient availability and crop growth: a review. Eng. Life Sci. 12:242-57.

Purwanto. 2009 Pertumbuhan dan Hasil Empat Varietas Padi (Oryza sativa L.) Pada Sistem Pertanian Organik, Semiorganik dan Pertanian Konvensional. Fakultas Pertanian. Universitas Gadjah Mada. Yogyakarata. Tesis.

Schröder, J. 2005. Revisiting the agronomic benefits of manure: a correct assessment and exploitation of its fertilizer value spares the environment. Bioresource Technology, 96(2), 253-261.

Shima, E., Svoboda, I., Tsutsumi, S., \& Ohkubo, H. 2002. Waste management systems of dairy cattle farms in Japan. Water Science and Technology, 45(12): 6369.
Sulistiani, R. 2006. Pengaruh Macam Pupuk Organik Cair Terhadap Pertumbuhan dan Hasil Tanaman (Kailan, Sawi, dan Selada). Universitas Muhammadiyah Malang. Tesis. 